\title{
War and the White Rhinos
}

\author{
Kai Curry-Lindahl
}

Until 1963 the main population of the northern square-lipped (white) rhino was in the Garamba National Park, in the Congo (now Zaire) where they had increased to over 1200 . That year armed rebels occupied the park, and when three years later they had been driven out, the rhinos had been drastically reduced: numbers were thought to be below 50 . Dr. Curry-Lindahl describes what he found in 1966 and 1967.

The northern race of the square-lipped rhinoceros Ceratotherium simum cottoni was once widely distributed in Africa north of the equator, but persecution has exterminated it over large areas. It is now known to occur only in south-western Sudan, north-eastern Congo (Kinshasa) and north-western Uganda. It is uncertain whether it still exists in northern Ubangui, in the Central African Republic.

In the Sudan, where for more than ten years its range has been affected by war and serious disturbances, virtually nothing is known of its present status. In Uganda numbers dropped from about 350 in 1955 to 80 in 1962 and about 20-25 in 1969 (Cave 1963, Simon 1970); the twelve introduced into the Murchison Falls National Park in 1960, despite two being poached, increased to 18 in 1971. But the bulk of the population before 1963 was in the Garamba National Park in north-eastern Congo, in the Uele area. There, since 1938, it had been virtually undisturbed, and, thanks to the continuous research which characterised the Congo national parks before 1960, population figures are known for several periods (see the Table on page 264).

The Garamba National Park was established in 1938 primarily to protect both the square-lipped rhinoceros and the giraffe Giraffa camelopardalis, which do not occur elsewhere in the Congo. The rhino was rare in the park, with probably not more than 100 animals. But with total protection numbers began to increase at an accelerating rate, indicating an astonishingly high rate of reproduction. In 1950-52 there were $250-300$; in 1956, 730; in 1960, 1190, and in 1963, when the last count was made before rebel forces from the Sudan invaded the Garamba and occupied a considerable part of the Congo, the figure was 1202. For the next three years there was heavy fighting in and around the park, and nothing was known about the wildlife situation.

In April-May 1966 I was invited as representative of IUCN, to accompany the Congo Minister of Agriculture on a three-week inspection tour of the provinces devastated in the fighting (CurryLindahl 1966, a, b, c; Oryx , August 1966). This mission, the first visit of a Central Government Minister to the Uele, Kibali-Ituri and Northern Kivu regions after liberation, (although eight isolated rebel pockets were still operating), gave high priority to conservation problems. The many conflicting reports made it difficult to get a clear picture of what precisely had happened in the Garamba, and the following account combines what I saw myself with information mainly from national park officials and other trustworthy sources. 


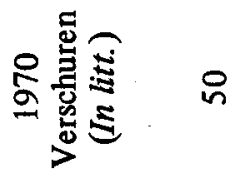

윰.

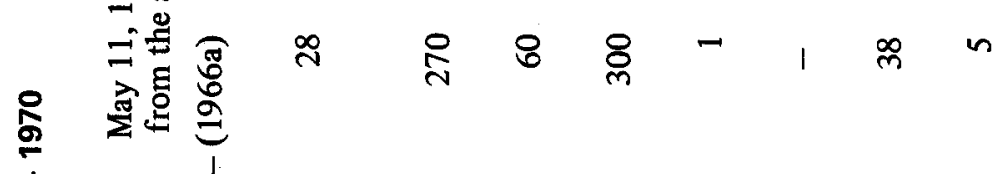

品

点

总要要

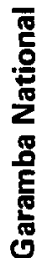

$\hat{6} .5$

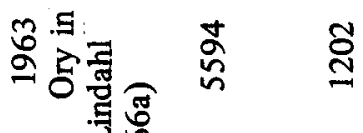

$\stackrel{\infty}{ \pm}$

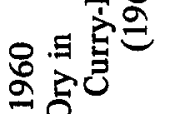

$\stackrel{2}{2} \quad \stackrel{\infty}{2}$

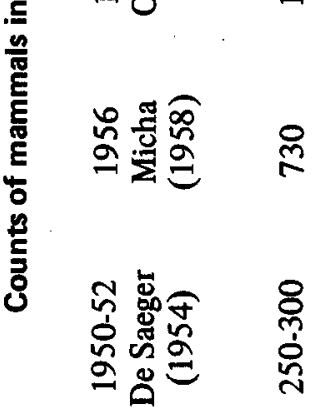




\section{The Invasion}

Up to 1963 poaching had increased very little following independence. Poachers from the Sudan often raided the park's northern sector, but the Sudanese authorities and the park rangers had some control. In 1963 the situation changed abruptly when well-armed rebel forces from bases in the Sudan occupied the Garamba completely, and later the whole north-eastern Congo. The park conservators and rangers were helpless against the rebels. The leaders, with plenty of money at their disposal, paid their soldiers astonishingly high wages so it was not difficult to get new recruits, and 77 rangers deserted to the rebels; nineteen who remained loyal soon had to flee into the bush. The national park was literally abandoned, and then proclaimed an open hunting area for all local people.

The square-lipped rhino with its confiding habits and mild temper was an obvious victim, and in 1966 nobody could give even an approximate figure of how many had been killed. National park officials said between 100 and 200 , and 37 skulls had been found in the national park that year. However, Père Plaillet of the Catholic Mission in Bunia told me that in April-May 1965 he had seen at least 200 , possibly as many as 400 rhino horns at the headquarters of the territorial administrator at Faradje, nearest town to the Garamba. They had been prepared with an oily substance, probably against termites and ants. Stacked upright and close together they covered almost the whole floor of a terrace I measured to be $10.5 \times 3 \mathrm{~m}$. M. Albert Couillier, Chief of the Police of the Kibali-Ituri province, whose boundaries march with those of Garamba on the eastern and south-eastern sides, told me that in February 1966 he saw about 100 rhino horns on the same terrace. People in Faradje said that the mercenaries were more occupied hunting rhinos than fighting rebels. But the German mercenaries stationed at Faradje since the end of March 1966 claimed it was the Sudanese poachers and A.N.C. soldiers under Congolese command who had massacred rhinos and other game in the park.

The Territorial Administrator was away when I visited Faradje, but his assistant told me that all the rhino horns kept at Faradje had been sequestered and sold. Rhino horns were still kept in a store house belonging to local authorities, but the man who had the keys was said to be absent. Through a window I saw about 50 large horns.

These three reports reveal that at least 350-550 rhinos had been killed and their horns had passed through Faradje; to this number must be added thinos killed by rebels, mercenaries and Sudanese poachers. A year later about 500 square-lipped rhino horns were found in Mombasa harbour awaiting dispatch (illegally) to the far East.

\section{Conditions in the National Park}

During an eight-hour drive in the southern sector of the Garamba, on May 6, 1966, I observed 19 rhinos, and at every stop we saw them. Some were close to us and did not seem to be panicked by the three cars. I got the impression that there must be a fairly good population in this sector, of which I visited only a fraction. But the northern sector was 
empty of rhinos and other game (except one lelwel hartebeest), and so were the western and eastern peripheries of the national park. In a flight on May 11, in a small single-engine aircraft, covering almost all the rest of the park, together with Pere Plaillet and Mr. Maurice Nelis, we counted only 28 rhinos, all in the southern sector. Driving in the southern sector we saw impressive herds of elephants, but they were nervous and apparently frightened by our car caravan. I counted $249-$ a high figure for the small area covered. But in the flight on May 11 we counted only 270 . It was obvious that large numbers had been killed.

Square-lipped rhinos are relatively easy to detect from the air in the Garamba savannas, where almost every rhino has one or more cattle egrets perched on its back; resting in the shade under a tree, on the other hand, they may remain unobserved from the air. So it was a very rough and perhaps optimistic estimate that 100 rhinos survived in the Garamba in 1966, especially when compared with the result of our counts $(19+28=47$ rhinos). If, however, the estimate was approximately correct, 900-1100 rhinos had been killed since 1963 .

Elephant numbers appeared to have dropped from 5,594 in 1963 to about 700 in 1966. This does not mean, however, that nearly 4000 had been killed. Previous elephant censuses in the Garamba had shown pronounced fluctuations, probably due to long-term migrations of which we do not know the pattern. (Cf. the situation in 1960 when their number was estimated at 9983.) Large numbers of hippos had been killed, and also buffaloes, giraffes and various antelopes in smaller numbers. On May 6 we saw large herds of buffaloes in the southern sector $(112+97+148$ in three herds +133 scattered in smaller groups or solitary). Altogether 490 were counted, and on the May 11 flight we counted 300 . Eighteen giraffes, counted on May 6, were not at all shy, nor were the other antelopes I saw. Uganda kob were the most numerous, with about 400 animals observed in the southern sector, scattered in the savannas on both sides of the road; lelwels numbered about 100 , and waterbuck, for which the habitats were not typical, only 13. Air counts on May 11 resulted in one giraffe, 38 lelwel and 5 waterbuck but no Uganda kob.

It was impossible to get any estimate of the numbers of hippopotamus killed. None were seen in the Dungu and Garamba rivers on May 6, though there were fresh tracks and droppings near the latter river. From the air on May 11 we saw about 60 in various aquatic areas in the centre of the national park. Altogether, the numbers and distribution of Uganda kob, elephant, buffalo, giraffe and lelwel suggested that the central part of the southern sector suffered least. This was confirmed by our flight over the other sectors five days later.

The figures obtained on May 6, 1966, along the Nagero-GarambaRiver road indicated an extremely high concentration of animals, except for giraffe, compared with Verschuren's figures (1958) along the same road in 1951. His maximum figures for one day's count were rhino 5, elephant 41, buffalo 40, giraffe 40, lelwel 15 , kob 24 .

\section{Recommendations}

Our recommendations to the Minister of Agriculture, which were accepted, strongly urged the government to arm the national park rangers, 
patrol the park boundaries constantly, particularly along the Sudanese border, make a census of all larger mammals as soon as possible, ensure that all military personnel received strict orders to respect the regulations of the national park and, when necessary, to defend it, and treat all sequestered rhino horns as the property of the central government and not, as at that time, of the local authorities.

However, the difficulties in the Garamba continued, chiefly due to the chaotic situation prevailing in the Sudan where a guerrilla war ravaged the area along the Congo border, and Sudanese poaching continued. During my stay in May 1967 at the Ministry of Agriculture in Kinshasa an urgent cable from the park's Conservator asked for help against armed rebels who had again invaded the park and were killing several rhinos daily, taking only the horns. I immediately saw the Minister of Agriculture and the Secretary General of the same ministry, and soldiers were sent to drive out the poachers, with strict orders to respect the national park.

In 1969, Dr. Jacques Verschuren was appointed Director General of the New Institut National Congolais pour la Conservation de la Nature, which is responsible for the administration of the Congo national parks. Early in 1970 he reported (in litt.) that he estimated the population of the square-lipped rhino in the Garamba at about 50 individuals (Oryx, May 1970), later reduced, after further incursions by Sudanese poachers to only 20-30 animals. In April this year came news that the latest white rhino count showed 252 animals, but according to Dr. Verschuren (in litt. \& verbally) this figure is far from being correct. Hence the situation is still very critical, when it is remembered that the animals in the Garamba and Murchison Falls National Parks, about 50 individuals altogether, and the $80-100$ in the Ajai Sanctuary, in the West Nile Province, may be the only surviving populations of the northern race anywhere.

\section{References}

CAVE, A.J.E. 1963 The white rhino in Uganda. Oryx 7: 26-29.

CURRY-LINDAHL, K. 1966 a. Rapport à Son Excellence le Ministre de l'Agriculture du Gouvernement du Congo sur les Parcs Nationaux Albert et la Garamba après la visite effectuée dans ces réserves en Avril-Mai 1966. Mimeographed, pp. 1-27.

1966 b. Report to the International Commission on National Parks of the IUCN on an inspection tour to the Albert and Garamba National Parks in the Congo, April 27 - May 14, 1966, by invitation of the Central Government of the Congo. Mimeographed pp. 1-19.

1966 c. The current situation in the Albert and Garamba National Parks, Congo. IUCN Bulletin 1: 3 ..

DE SAEGER, H. 1954. Introduction. Exploration du Parc National de la Garamba. Mission H. De Saeger. 1: 1-107.

MICHA, M. 1958. Le Rhinocéros blanc. Zoo. No.4: 1-4.

SIMON, N 1966. Red Data Book. Vol. 1, Lausanne.

VERSCHUREN, J. 1958. Ecologie et biologie des grands mammifères (Primates, Carnivores, Ongulés). Exploration du Parc National de la Garamba. Mission H. De Saeger. 9: 1-225. 